\title{
Teaching European Studies in Australia: Fostering Cultural and Historical Literacy through the Narrative Imagination
}

\author{
Danica Jenkins \\ The University of Sydney \\ danica.jenkins@sydney.edu.au
}

\begin{abstract}
One of the main problems we face in teaching European Studies in the Australian university context is the lack of cultural and historical literacy about Europe among the current cohort of students. Drawing on Martha Nussbaum's concept of the 'narrative imagination', this paper suggests that novels, films and other literary material can help our students penetrate unfamiliar cultural and historical environments. This is because narrative provides the context to help students understand complex dynamics at play in unfamiliar situations, and makes this context meaningful by putting it into humanistic, not scientific terms. It is above all an epistemology based on the use of 'empathy' as a device to deepen historical and cultural understanding. While there are certainly caveats to using literary texts in an academic environment of historical or social inquiry, as long we are cognizant of the truth-value of the literary epistemological framework, that is, we understand that they do not aim to establish veritable fact, but instead provoke an emotional response from us, such texts remain useful pedagogical tools for fostering cultural and historical literacy amongst our students.
\end{abstract}

Keywords: Australian Tertiary Education; Cultural Literacy; Epistemology of Literature; European Studies; Historical Literacy; Narrative Imagination.

\section{Introduction}

"Only art penetrates ... the seeming realities of this world. There is another reality, the genuine one, which we lose sight of. This other reality is always sending us hints, which without art, we can’t receive" (Saul Bellow, 1976).1

One of the main problems we face in teaching European Studies in the Australian university context is the lack of cultural literacy or even 'general knowledge' about Europe among the current cohort of students. By this I mean the difficulty in situating contemporary European affairs, or even the basic functioning of the European Union, within appropriate cultural and historical contexts. What is missing is not the intellectual access to cognitive frameworks, but the breadth of knowledge required to derive meaning from them. How can we overcome these blind spots in teaching European Studies? As 'Europeanists', more often than not working in multi- or interdisciplinary frameworks, we must think outside of unidimensional epistemologies and encourage our students to do the same. This necessarily involves finding meaningful ways to bridge gaps in European historical and cultural literacy. Drawing on Martha Nussbaum's concept of the 'narrative imagination', I suggest that novels, films and

\footnotetext{
${ }^{1}$ Saul Bellow, 'Nobel Lecture' December 12, 1976, in Sture Allen (ed.) Nobel Lectures in Literature, 1968-1980 (Singapore; New Jersey; London; Hong Kong: World Scientific, 1993): 135.
} 
other literary material can help us penetrate unfamiliar cultural and historical contexts. By embracing Aristotelian rhetorical dimensions of truth-seeking and understanding, the literary imagination enables us to 'comprehend the motives and choices of people different from ourselves,' by seeing them 'as sharing many problems and possibilities with us.'2 It is for this reason that a compelling narrative can engage students in ways that conventional pedagogic methods and disciplinary frameworks may not. Moreover, using literary texts in conjunction with historical texts and social theory can help to reinforce the idea that European history is not a single, synthesized narrative, but rather the changeable product of different interpretations, interests and perspectives which must be approached critically. Thus, while novel-reading and filmwatching cannot take the place of formal historical enquiry or empirical frameworks of analysis, the use of this material to teach within a pedagogically and academically 'controlled' environment can provide our students with a means to understand European socio-cultural and historical contexts that are vital to the meaningful comprehension of contemporary Europe and its place in the world today.

\section{The Anglophone mindset and European cultural literacy in Australia}

In his influential and controversial Cultural Literacy: What Every American Needs to Know (1987), E.D. Hirsch coined the term 'cultural literacy' broadly as the ability to understand and participate in a given culture. ${ }^{3}$ Hirsch refers to the vast reservoir of ideas, names, events, dates, movements and works of the imagination or science that enables members of a culture to understand culturally-conditioned allusions and references to past events, and to participate in public discourse and debate. Although Hirsch was writing in terms of what he saw as endemic failures of the American education system, contemporary commentators have since expanded the concept more comprehensively, reflecting the increased need for students and professionals to engage in cross-disciplinary and multicultural collaboration. 4 In this latter instance, cultural literacy might be defined as the possession of a broad range of knowledge about different cultural groups, coupled with an awareness of how various cultures and their histories impact the way business, governance, and international relations are conducted in the modern global environment. 5 In terms of European Studies in an Australian educational environment, cultural literacy would be the ability to understand the culturally- and historically-determined characteristics of contemporary European affairs, in particular how different European nations interact with one another qua their national histories and identities on the one hand, and their relationship to the supranational structure of the EU on the other.

This form of literacy seems to have weakened over the years, and there are several possible reasons for this. Firstly, our location and demography. The results of the latest national census reveal that for the first time in Australia's history, the majority of

\footnotetext{
${ }^{2}$ Martha C. Nussbaum, Cultivating Humanity: A Classical Defense of Reform in Liberal Education (Cambridge; Massachusetts; London; England: Harvard University Press, 1998): 85.

3 E. D. Hirsch, Cultural Literacy: What Every American Needs to Know (Houghton \& Mifflin; Boston, 1987).

4 Gabriel García Ochoa, Sarah McDonald and Nicholas Monk. 'Embedding Cultural Literacy in Higher Education: A New Approach', Intercultural Education, 27/6 (2016): 546.

5 See Charles W.L. Hill (ed.), Global business today, 8th edition (New York: McGraw-Hill, 2013): 86-87.; and Chengxin Pan, 'Cross-Cultural Literacy as Social Knowledge: Implications for Australia's Understanding of China', in Chengxin Pan and David Walker (eds.), Australia and China: Challenges and Ideas in Cross-Cultural Engagement (Beijing: China Social Sciences Press, 2015): 308-16.
} 
people born overseas are now from Asia, not Europe. ${ }^{6}$ Yet this demographic expression of Australia's reorientation away from Europe towards Asia has a long history, particularly since the 1980 s when the turn towards Asian markets largely shifted Australia's national consciousness and world view away from the British 'motherland' towards the Asia Pacific. Secondly, Australia's isolated location has often been cited as the reason for our Anglophone monolingualism. Unlike European students, Australians, having grown up speaking the 'world language' as a mother tongue, simply 'do not have multilingualism reinforced throughout the school years'. 7 And yet, Australia remains an incredibly diverse nation. The recent census also revealed that many Australians were born in close to 200 different countries, and that we have more than 300 different ancestries and speak more than 300 different languages in our homes. ${ }^{8}$ Our problem thus relates not to our linguistic diversity and multiculturalism, but to what Michael Clyne once termed the 'monolingual mindset' of Australian culture. 9 A fervent advocate for language education programmes in Australian schools, Clyne highlighted the benefits of multilingualism for social cohesion and intercultural understanding amongst students, regardless of their linguistic background.10 However, as in other Anglophone countries, the global power of English as a lingua franca means that Australian educational policy remains grounded in a monolingual norm. ${ }^{11}$ Even though the former federal Labor government (2007-2013) introduced new education policies that recognized the usefulness of learning languages, policy emphasis has been on 'Asian Literacy' and is underpinned broadly by an economic impetus. ${ }^{12}$ Not only does this approach exclude the cognitive, social and intercultural benefits of learning a language, but its focus on Asia side lines other languages, such as those which are European. ${ }^{13}$ Accordingly, insofar as it has been wellestablished that language is the gateway to intercultural understanding, both Australia's Anglophone mindset and its prioritized links to Asia through geopolitical, economic and educational policy initiatives are likely reasons for retrograde European cultural literacy in Australia.

\footnotetext{
${ }^{6}$ Australian Bureau of Statistics, ‘Census Reveals: We're a Fast Changing Nation,' News Release, 27 June 2017, accessed 16 December 2017 from: http://www.abs.gov.au/ausstats/abs@.nsf/mediareleasesbytitle/ BA4418859C270D68CA2581BFoo1E65B3?Open Document.

7 Anna Dabrowski, 'How to Make Australia More Bilingual', The Conversation, 18 June 2015, accessed 5 December 2017 from: https://theconversation.com/how-to-make-australia-more-bilingual-42609

8 Australian Bureau of Statistics, '2024.0 - Census of Population and Housing: Australia Revealed, 2016. Australia Today: The Way We Live Now', Summary, 27 June 2017, accessed 16 December from

http://www.abs.gov.au/ausstats/abs@.nsf/mf/2024.0

9 Michael Clyne, 'The Monolingual Mindset as an Impediment to the Development of Plurilingual Potential in Australia,' Sociolinguistic Studies 2/3 (2008): 347-366.

${ }^{10}$ John Hajek and Yvette Slaughter (eds.), 'Introduction', in Challenging the Monolingual Mindset (Bristol: Channel View Publications, 2014): 2.

${ }^{11}$ Ruth Fielding, Multilingualism in the Australian Suburbs: A Framework for Exploring Bilingual Identity (Singapore: Springer Singapore, 2015): 2.

12 Fielding states: 'The more recent introduction of the National Asian Languages and Studies in Schools Program (NALSSP) has indicated the viewpoint of the former Federal government (2007-2013) that languages are useful for Australia in terms of increasing students' skills in intercultural communication. Communication with Asian countries is seen by the policy-makers as particularly important, although there is less emphasis upon the learning of languages for communication with other people within Australia'. See Fielding, 8.

${ }^{13}$ Fielding states that although the policy focus on 'Asian Literacy' does acknowledge the importance of language learning, 'the focus upon Asia from an economic rationale, to the exclusion of language learning for its cognitive, social and intercultural benefits, means a potential relegation of the study of any other languages and certainly children's home languages'. See Fielding, 13.
} 


\section{Cultural literacy and the narrative imagination}

For us Europeanists, the question remains: how do we foster European cultural literacy in Australian universities by alternative means? How do we make this information, so geographically, historically and culturally distant from the students in our contemporary Australian classrooms, meaningful enough - and more importantly manageable enough - to teach? Hirsch himself offers little insight: although his major assertions are correct, the implications of it are not. For Estes, Gutman and Harrison, Hirsch's assumption that 'the foundation of literacy is the ability to recall and associate a superficial level of knowledge' overlooks the necessity of constructing historical and cultural meaning from learned facts, which leads us right back to the root cause of our problem: students will not remember what they don't understand. ${ }^{14}$ Facts about culture must therefore be considered within their social and historical contexts and understood as interconnected phenomena, which reverberate in unexpected ways. Better yet, if discrete cultural facts are placed within the framework of a broader narrative, then we start to engage what Nussbaum calls the 'narrative imagination', a cognitive tool which allows us to 'see unobvious connections between sequences of human actions' and to 'recognize their likely consequences, intended and unintended'. ${ }^{15}$ Novelist and journalist Rebecca West proclaims in the end of her travelogue through the former Yugoslavia, Black Lamb and Grey Falcon (1942), 'I was obliged to write a long and complicated history... since it was my aim to show the past side by side with the present it created.' 16 West recognized implicitly the need for narrative to make sense of complex cultures and histories, and neither of these is more complex than in the Balkans. 'As we grow older and see the ends of stories as well as their beginnings', she states, 'we realise that to the people who take part in them it is almost of greater importance that they should be stories, that they should form a recognizable pattern, than that they should be happy or tragic' ${ }^{17}$ More importantly, she continues, narrative not only helps individuals apprehend the significance of historical events in relation to a broader pattern of self-understanding, but enables nations to do the same. ${ }^{18}$ In its encompassing of both the individual and the collective aspects of identity formation, the narrative imagination is thus a useful epistemology for European Studies as it can help our students to consider the long-term significance of historical events for different cultures, by linking past events meaningfully the present through narrative conventions.

Studies of nationalism and national identity have long pointed to the power of narrative in the self-understanding of nations and cultures. Ernest Gellner's notion of 'high culture' posits modern nationalism as the 'entry to, participation in, identification with, a literate high culture which is co-extensive with an entire political unit and its total populations.' 19 Gellner suggests that high culture is closely associated with the modern state and its transition from agrarian to industrial society, insofar as it connects the politics, culture and territory of a given population together as a single entity in place of the localized structures of small tribal groups. ${ }^{20}$ Yet while Gellner largely suggests a radical break between folk culture and high culture, it is important

\footnotetext{
14 Estes, Gutman and Harrison, 15.

15 Martha Nussbaum, summarized by Inga Clendinnen, True Stories (Sydney, ABC Books: 200o): 6.

${ }^{16}$ Rebecca West, Black Lamb and Grey Falcon: A Journey Through Yugoslavia [1942], (Edinburgh: Canongate

Books, 1992): 1089 .

17 Ibid, 55 .

18 Ibid, $55-56$.

19 Ernest Gellner, Nations and Nationalism (Ithaca: Cornell University Press, 1983): 95.

${ }^{20}$ Ibid, 57.
} 
to recognize that this high culture is often imagined through reference to a historical past. ${ }^{21}$ While Gellner himself implicitly alludes to the advantages of an available 'old high culture' as an asset for modern state-formation and cultural self-definition, ${ }^{22}$ Anthony D. Smith makes this connection explicit, stating that 'old' cultures were not simply replaced, but were 'adapted, purified, enlarged and diffused' through selfconscious nationalist movements. ${ }^{23}$ For Smith, the creation of modern nations requires the mobilization of a shared historical past, which is used to unite members of the group through a sense of common destiny and connection to an ancestral homeland. ${ }^{24}$ The links to this past are fashioned from shared memories, traditions, myths and symbols via processes of collective remembering, however Smith also recognizes that even if such a past does not exist, one must be created through a coherent national narrative. ${ }^{25}$ Benedict Anderson, likewise, underscores the importance of the narrative process in 'imagining' a nation, suggesting that through narrative culture a population of people, who cannot possibly all know each other, can still imagine themselves as a coherent collective body. ${ }^{26}$ For Anderson, it was largely through the rise of print culture, and especially the narrative structures of the realist novel, that a way of imagining was cultivated which integrated with the self and with the nation. ${ }^{27}$

What this tells us is that the process by which mere existence is transformed into meaningful being, and historical facts recast into cultural self-understanding, is underpinned by storytelling. Even for pre-modern communities and civilizations, epics, folklore and ballads fulfilled this basic narrative function of defining a collectivity. ${ }^{28}$ In fact, the ability of human beings to cooperate in large numbers at all, and hence the story of our survival, argues historian Yuval Noah Harari, arises precisely from our unique capacity to imagine, and to create and believe in fiction collectively, whether this be in the form of Aboriginal dreamtime stories, the biblical creation, or the nationalist myths of modern states. ${ }^{29}$ Moreover, it is through the narrative imagination that historical pasts are linked to the present in ways that are meaningful to a given culture. As a pedagogical tool, how then can we use narrative in our classrooms to foster cognizance of the cultural links between the past and the present in the contemporary European context? We already know that storytelling is vital to the self-understanding of collective groups, and that the significance of disparate events becomes clear when we link them through narrative as 'sequences of human actions'. $3^{\circ}$ Daniel Reynaud suggests that both the historian and the fiction writer give us access to the past by 'making its foreignness familiar', by explaining it in

\footnotetext{
${ }^{21}$ Ibid, 55-56.

22 Ibid, 85.

23 Anthony D. Smith, 'Memory and Modernity: Reflections on Ernest Gellner's Theory of Nationalism', Nations and Nationalism 2/3 (1996): 380.

24 Ibid, 383.

25 Smith states: 'there is considerable evidence that modern nations are connected with earlier ethnic categories and communities and created out of pre-existing origin myths, ethnic cultures and shared memories' (385), and that 'a nation must have a navel, and if they have not got one, we must start by inventing one' (387).

${ }^{26}$ Benedict Anderson, Imagined Communities, 2nd Edition (London; New York: Verso, 2006): 6.

27 Ibid, 26-33.

${ }_{28}$ Philip V. Bohlman recognizes the proto-national narratives of the epic and the ballad as those which possessed the power to transform local stories into national histories. He writes: 'These stories, often passed orally from singer to singer and from community to community, were also part of a much larger historical complex, within which the threads of nascent national identity were woven together to form the whole that unified people in the early stages of nationhood'. See Philip V. Bohlman, 'Ch 12: The Nation in Song', in Stefan Berger, Linas Eriksonas, and Andrew Mycock, (eds.) Narrating the Nation: Representations in History, Media and the Arts, Vol. 11 (New York: Berghahn Books, 2008): 253-254.

29 Yuval Noah Harari, Sapiens: A Brief History of Humankind (New York: Harper Collins, 2015): 25.

${ }^{30}$ Nussbaum, summarised by Inga Clendinnen, ibid 6.
} 
terms of the present. ${ }^{31}$ Yet what is so useful about fiction is that not only documents historical events but illustrates their significance for the culture about which the fiction is about: 'like history', Reynaud states, 'written and cinematic historical fiction speaks to the present, but uses the past to address contemporary issues.' 32 Unlike the historian, the novelist or filmmaker may approach the past subjectively. This allows fictional narratives to explore aspects of history which a history or even social theory may not contemplate, such as personal motivations and attitudes, which can offer insights into the emotional significance of events for different cultures and the ways in which they are utilized to affirm or deny the validity of national myths. 33 Therefore, not only can the literary epistemology enlighten our students to the values and concerns of a 'foreign' historical period, but it can also demonstrate how the events from that time intersect with current cultural concerns and attitudes, providing useful insights into the mythic significance of events for a particular culture.

\section{The narrative imagination and the European novel}

When we read the fictions of great national writers such as Theodor Tolstoy, Leo Tolstoy, or Jane Austen, for example, we penetrate not simply the Zeitgeist of the novel, but the broader contours of its national culture. For Anderson, what is important to the role of fiction in imagining the nation, is that the world evoked by the novel encompasses events happening simultaneously in a geographically defined area, independently of, and beyond the experience of particular individuals. 34 Yet not only did the rise of the novel make it possible for people sharing a national culture to 'think about themselves, and to relate to others, in profoundly new ways', but the novel's imagined world also gives readers such as ourselves, 'a precise analogue of the idea of a nation.' 35 This is why, in twenty-first century Australia, our students might be able to access unfamiliar cultures via characters' concerns, values and preoccupations in the historical novel, and apply these to the pressing issues of contemporary contexts. By reading Austen's Pride and Prejudice (1813), for example, we can connect the nineteenth-century social anxieties of England's provincial middle class to the fear of dispossession and increasingly fragmented self-understanding among this class in Britain today. This is a particularly useful cultural insight for students who are attempting to penetrate modern British issues of class and status, by encouraging them to consider how the insecurities of nineteenth-century gentrified England connect to a recent European phenomenon as seismic as Brexit.

With regard to how cultural tensions reconcile themselves in the formal structures of the nation, Franco Moretti suggests that the novel 'functions as the symbolic form of the nation-state', not because it conceals the nation's internal differences, 'like a monument or an anthem', but because it 'manages to turn them into a story'. ${ }^{6}$ In Anna Karenina (1877), for example, Tolstoy negotiates what it means to be Russian at time of profound intellectual debate. His characters' worries and their movements across the crumbling Czarist Empire represent a nation divided over the direction it should take to modernize, either by Westernization, or defence of its Byzantine, Orthodox and Slavic heritage. Anna's tragedy encapsulates the irresolution over this destiny and its

\footnotetext{
${ }^{31}$ Daniel Reynaud, 'Dealing with Historical Movies in the History and English Classroom', Teach 2/2 (2008): 48.

$3^{2}$ Ibid, 49-52.

33 Ibid, 49-52.

34 Summarized by Jonathan Culler, 'Grounds of Comparison: Around the Work of Benedict Anderson', Diacritics 29/4 (1999): 23.

35 Anderson, 36 and 26, my emphasis.

${ }^{36}$ Franco Moretti, Atlas of the European Novel, 180o-19oo (London; New York: Verso, 1999): 20.
} 
ongoing legacy in Russian cultural self-understanding. In Effi Briest (1894), similarly, Fontane's depiction of his protagonist's unhappy marriage problematizes the dominance of traditional Prussian values in the new German state and ambivalence over German identity despite formal unification. Yet while these two novels are unique products of time and place, they also crystallise aspects of Russian and German identity which in part remain unresolved today. Such literature can thus provide our students with the tools to understand the cultural and historical determinants of different European identities, and their internal tensions, which continue to influence their interactions with one another within the larger context of contemporary European culture.

\section{Cinema and the 'authenticity of affect'}

It is not just literature which engages our narrative imagination in this way. If the purpose of the novel, as Milan Kundera maintains, 'is to discover what only the novel can discover', 37 then the purpose of cinema is to render meaningful what only it can discover. Cinema as an art form of visual technology allows it to seek something more than the sort of representation or documentation students would find in history books or the modern political praxis: it can register the impact of disparate and long-term historical events in a snapshot by converging them into a set of images, or even a single image, on a screen. As David Bordwell writes, 'literary texts conjure up worlds from mere words, but film presents us with a rich array of images and sounds that immediately conjures up a dense realm.' ${ }^{3} 8$ For Walter Benjamin, one of the first critical theorists interested in the political implications of film, screen culture is capable of exposing viewers to otherwise inapprehensible aspects of history and culture. 39 Cinema, according to Benjamin, is an art form produced for the masses, by virtue of which it necessarily takes on a social as well as aesthetic function - or rather, film's aesthetic and reproductive qualities enhance its broader social and cultural impact and role..$^{\circ}$ Film thus engages the narrative imagination in similar ways to literature, but by converging content and form into a 'dense realm' of verisimilitude, it offers a world which viewers can emotionally relate to through the visual impact of images. This is also what makes cinema particularly useful as a contextualization tool for Anglophone or monolingual students, whose cognitive access to the linguistically-determined aspects of different European cultures is likely be weak or missing.

In consideration of how to approach cinema as both an artistic and cultural text, Dino Murtic outlines some useful methodologies with which we can use cinema in the European Studies classroom. Drawing on the arguments of critical theorist Douglas Kellner, Murtic argues that films both incorporate the raw material of social history and social discourse, and through the narrative process are themselves transformed into social forces..$^{41}$ As a result, films become simultaneously 'witnesses to their era', and mediums through which past events receive appropriate cultural meaning. 42 Because of this, we should approach the moving image from beyond a formalist

\footnotetext{
37 Milan Kundera, The Art of the Novel (New York: Grove Press, 1987): 5 .

${ }^{8}$ David Bordwell, Poetics of Cinema (New York; Abingdon: Routledge, 2012): 110.

39 Summarized by Dino Murtic, Post-Yugoslav Cinema: Towards a Cosmopolitan Imagining (Houndmills; Basingstoke; Hampshire; New York: Palgrave Macmillan, 2015): 11-12.

$4^{\circ}$ Walter Benjamin, 'The Work of Art in the Age of Mechanical Reproduction', in Hanna Arendt (ed.)

Illuminations (New York: Shocken, 1968): 234.

${ }^{41}$ Ibid, 15.

${ }^{2}$ Ibid, 15. Murtic here cites Tomislav Šakić, 'Filmski svijet Veljka Bulajica: popriste susreta kolektivnog i privatnog', Hrvatski filmski ljetopis, 15 (2009): 19; 27.
} 
framework, by using a methodological apparatus that takes into account both content and form. 43 Under this method, films are analyzed beyond the surface of the aesthetic image, but in recognition of the fact that cinematic image itself can also capture the constitutive elements of a particular culture or socio-political environment.44 Text and context thus become a dialectic: we can use the film to read socio-cultural realities and historical events, and in turn social and historical context enables us to interpret and understand the film with more clarity and depth. 45

In the oeuvre of Pedro Almodóvar, for example, we can apprehend the evolving identity of post-Francoist Spain. From the lurid sexual freedom of his early experimental films, to the dark, crafted renegotiations of Francoist morality structures and questioning of traditional Spanish cultural symbols that have come to define his work, Almodóvar not only set about transgressing every taboo associated with Spain's fascist heritage but also normalizing these transgressions as assertions of a 'new' Spain. The visual aesthetic of his films splices the kitsch, colourful and camp with the 'dark, mad realm of Goya and Lorca';46 a trope perhaps best encapsulated by his preoccupation with transsexual characters. This duality extends to Almodóvar's visual representation of place: as Marvin D'Lugo points out, where Francoist cinema constructed its own ideal of the Spanish nation against the 'social and political deviance of the urban lifestyles of Madrid and Barcelona', Almodóvar's films foreground the city as a site of vibrant Spanish cultural identity. 47 It is only much later in Volver (2006) that Almodóvar finally returns to the provincial region of La Mancha, his birthplace and what he calls 'deep Spain', 48 a 'region with a great tradition of tragedies,' 49 to face unresolved aspects of the Spanish past and the grief that remains at the heart of a profoundly resilient population. Drawing on the dialectic method outlined above, what these images communicate to viewers cognizant of the context of Spain's twentieth-century legacy of military dictatorship and civil war, is the travails of a modern European nation still coming to terms with its past. Used in conjunction with historical and other social science educational resources, such films can provide students with useful insights into the long-lasting cultural impact of war and dictatorship. Likewise, by converging these legacies into a set of narratively connected cinematic images, film offers an emotional world that students can relate to, meaning they will glean a deeper understanding of the ways in which historical experiences continue to resonate in the tensions and concerns of contemporary contexts.

A point we must remind our students, however, is that cinematic fiction, like other literary fictions, is 'narrated through and through'. ${ }^{\circ}$ From the camera position, to the choreography of characters and props, to the framing of shots and lines of dialogue, 'everything, including the solid environment and behaviours we detect, is produced by the film's narration.' ${ }^{1}$ Nevertheless, as the very nature of the camera aims to mimic

\footnotetext{
43 Ibid, 18.

44 In making this point, Murtic draws attention to the methodological apparatuses of 'political hermeneutics', advanced by Steve Best and Douglas Kellner, in '(Re) watching Television: Notes Toward a Political Criticism', Diacritics, 17/ 2 (1987): 97-113; and 'diagnostic critique', proposed by Douglas Kellner, in Cinema Wars: Hollywood Film and Politics in the Bush-Cheney Era (Oxford: Wiley-Blackwell: 2010).

45 Ibid, 18.

${ }^{46}$ Peter Conrad, 'Interview: Pedro Almodóvar', The Guardian, 13 August 2006. Available at: https://www.theguardian.com/film/2006/aug/13/features.review1

47 Marvin D'Lugo, 'Almodóvar's City of Desire,' Quarterly Review of Film and Video XIII, 4 (1991): 47.

48 Pedro Almodóvar, in interview with Conrad, ibid.

49 Pedro Almodóvar in interview with Carlo D'Ursi, 'Don Pedro de La Mancha', Cineuropa, 14 March 2006. Available at: http://cineuropa.org/ff.aspx?t=ffocusinterview\&l=en\&tid=1205\&did=62911

$5^{\circ}$ Ibid, 110 .

${ }^{1}$ Ibid, 110.
} 
human eyesight by 'recording events in a way that is similar to how we see them in real life', and with authenticity also enhanced by realist cinema codes such as sets and costumes, Reynaud warns that the use of film as a pedagogical tool is potentially problematic, as students might not be sufficiently discriminating to its constructed nature. ${ }^{2}$ The problem, he contends, is that 'films often appear as unmediated reflections of truth, whereas in fact they always construct a truth.'53 Moreover in many cases cinema, like literature, is instrumentalised to tell untruths - the potential for error and oversimplification is hence one of the main problems historians have with the use of literary faculties in historical disciplines. Indeed, literary and historical texts are not bound by the same codes limitations of inquiry. Where the historian or social theorist must work largely within the confines of empirical enquiry and factual evidence, the novelist or filmmaker is free to invent or overlook material as it suits their narrative purpose.54 Films in particular are also impacted by the commercial concerns of production, which means that filmmakers will often exaggerate, simplify or manipulate facts to deepen the melodramatic mode of the film to ensure it reaches the broadest possible audience. 55

While these are all important points to keep in mind when using literary texts as teaching tools, it is also necessary to remember that historical texts themselves are often mediated and constructed from a particular perspective or methodological framework. As Michael Conway puts it, most students already approach history as a set narrative - 'a process that reinforces the mistaken idea that the past can be synthesized into a single, standardized chronicle of several hundred pages. 56 Yet, as Conway argues, 'history is anything but agreeable... It is a collection of historians exchanging different, often conflicting analyses. 57 If students are to master the analytical faculties required of them in academic environments, then it is essential that they approach all academic texts with critical scrutiny and read a diverse array of different perspectives on a given topic. In this manner, literary texts are simply one more mode of historical and socio-cultural inquiry which offer insights into a specific situation, and so these must be read critically in conjunction with other academic material. Furthermore, although abstract theoretical ideas and detailed historical or social analysis may be absent in the literary environment, the epistemology of film and literature renders situations meaningful to us 'through the force of emotional rather than rational persuasion.' 58 This is because their imperative is not to establish veritable facts, but to provoke an emotional response from us - they aim to tell us about different cultures and different times by expanding our sympathies in ways that real life cannot. Historical detail and even plausibility can be suspended under the storytelling prerogative, as authenticity in the literary context is not based on veracity, but rather on what Owen Evans calls the 'authenticity of affect.'59 In other words, by condensing

\footnotetext{
$5^{2}$ Reynaud, 49-51. He states: 'While teachers may recognize the tenuous relationships between history, film, and truth, students are often not so discriminating. As we have seen, filmmakers adopt many strategies to make their films more credible, and when these are overtly or implicitly given the label of "truth" or "true story", they are often read as being true in every respect' (51).

53 Ibid, 49.

54 Ibid, 49.

55 See Owen Evans, 'Redeeming the demon? The Legacy of the Stasi in Das Leben der Anderen' Memory Studies, 3/2 (2010): 164-177 for a detailed analysis of this point in relation to the historical film, Das Leben der Anderen/The Lives of Others (2006).

${ }^{56}$ Michael Conway, 'The Problem with History Classes: Single-Perspective Narratives do Students a Gross Disservice', The Atlantic, 16 March 2015. Available at:

https://www.theatlantic.com/education/archive/2015/03/the-problem-with-history-classes/387823/

57 Ibid.

$5^{8}$ Ibid, 50 .

59 Ibid, 173.
} 
or exaggerating aspects of life through narrative conventions, literature and film produce something that 'lingers ... a residue, something we feel which is in excess of the representational system that produced it'. ${ }^{60}$ It is precisely from this 'residue' that historical and cultural literacy develops.

\section{Empathy and the narrative imagination}

Why it then that literature and film can resonate so strongly with us? How can they tell us things about peoples and cultures that other ways of seeing and understanding the world cannot? Why, as Saul Bellow stated in his 1976 Nobel-Prize winning speech, do we need art to 'receive the hints that reality sends to us'? ${ }^{61}$ It is because the literary epistemology, unlike others, is at its core a human one: we are learning about a particular environment through the interior experiences of another human being. For Nussbaum, engaging the literary imagination enables us to reach beyond our imagined sense of belonging with others within a shared community, and cultivate a 'capacity for sympathetic imagination that will enable us to comprehend the motives and choices of people different from ourselves'. ${ }^{62}$ Narrative can thus help us to build students' critical contextualization faculties by fostering their sense of historical empathy - the ability to understand the ideas, beliefs, and values of people living in a different time or place, and consider how these factors influenced their decision making. ${ }^{63}$ This is not purely an emotional process, like empathy in the traditional sense; nor is it based entirely on a historical methodology of analyzing a situation's determinants. It is a cognitive and logical process that takes into consideration the totality of a given environment - not just the circumstances that give rise to it, but how these circumstances impact the way human beings think and behave - by encouraging our students to think how they might behave in a similar situation. The literary epistemology is thus based on a philosophy of sameness despite difference, and so cultural literacy is acquired not by learning facts about unfamiliar places and times but instead by seeing how unknown historical and cultural phenomena converge in familiar human settings.

Narrative enables us to get behind what François Simiand refers to as histoire événementielle or 'event-centred history' to understand the culturally-determined reasons why people respond differently in times of crisis and transition. ${ }^{64}$ In Luc and Pierre Dardenne's Two Days, One Night (2014), the story of a multicultural workingclass Belgian community that pulls together during a the global financial crisis, illustrates the personal and social benefits of a culture grounded in a long history of workers' rights and civil liberties. In its exploration of interpersonal solidarity and the possible avenues for individual appeal against power, the film not only tells us about the nature and expectations of this kind of society during crisis, but it puts into perspective the long-term legacy of Western European pluralism and protection of individual rights vis-à-vis competing loci of power.

In comparison, Andrey Zvyagintsev's shattering portrayal of contemporary Russia in Leviathan (2014) reveals the civic implications of a very different history. With a

\footnotetext{
6o Patrick Phillips, 'Spectator, Audience and Response', in Jill Nelmes (ed.) Introduction to Film Studies

(Abingdon and New York: Routledge, 2007): 159, cited in Evans, 173.

${ }^{61}$ Bellow, in Allen, 135.

62 Ibid, 85.

63 Jeffery Nokes, Building Students' Historical Literacies: Learning to Read and Reason with Historical Texts and Evidence (New York: Routledge, 2013): 23-25.

64 Cited by Fernand Braudel, 'Ch 2: History and the Social Sciences', in Peter Burke (ed.), Economy and Society in Early Modern Europe: Essays from Annales (New York: Harper, 1972): 14.
} 
staggering record of upheaval and bloodshed in the twentieth century alone, and a tradition of civic suppression and autocracy that can be traced back from Vladimir Putin to the history of the Tsars, Russia is a country whose population has been through extremes of hardship and disillusionment that people in other industrialized nations might find hard to imagine. Unlike in the West, the longue durée of Eastern European history has been marked by the absence of individual rights and freedoms, and has instead consolidated around deep-rooted traditions of Caesaropapism and authoritarianism. These patterns of power and authority were largely replicated within the communist system, and remain a defining feature of social life in Putin's Russia today, albeit in new guises. Yet without the cooperation of our creative imaginations, it is often difficult to see the connections between contemporary social issues and the diachronic frameworks of what Braudel calls the 'old attitudes of thought and action'65 that underpin them. Zvyagintsev makes these connections explicit: his film illustrates how the institutional problems of post-communist transition have been compounded by behaviours of civic passivity and atomization that have been cultivated over centuries. His story of personal defeat in the face of state and ecclesiastical power exemplifies the outcome of a history bereft of civic rights and liberties, and shows us why these civic behaviours struggle to take root even in the Russia of today. In this sense, the film's titular 'Leviathan' is not the state under Putin, or even its spiritual unity with the Russian Orthodox Church; it is the monolith of Russian history as it lives on in the minds of people, beneath structural crises and changes, as 'cadres résistants, durs à mourir, parfois contre toute logique.'66

The pedagogical value of these films is their anatomization of the human impact of two very different long-term cultural developments in Europe. By virtue of their narrative appeal and focus on universal stories of conflict between individuals and places of power, we can apprehend the civic consequences of two vastly different histories because the weight of such histories is communicated to us through the everyday lives and concerns of human characters. As Nussbaum states, by means of 'expanding our sympathies that real life cannot cultivate sufficiently', the political promise of the literary imagination is that:

it can transport us, while remaining ourselves, into the life of another, revealing similarities but also profound differences between the life and thought of that other and [ourselves], and making them comprehensive. ${ }^{67}$

It is precisely at this nexus between sameness and difference that our students gain the tools of critical contextualization required to make sense of unknown or unfamiliar cultural and historical phenomena, insofar as we are not just asking them to recognize sameness despite difference, but rather to identify the specific cultural idiosyncrasies that reveal themselves after an initial process of empathetic identification. This is important, since one of the main messages we receive from these two films is that, for all their apparent exposure to the same globalizing forces, different cultures bring to bear distinct sets of historically-determined judgements, expectations and behaviours on similar social situations.

\footnotetext{
65 Fernand Braudel, 'Histoire et Sciences Sociales: La longue durée,' Annales 13/4 (1958): 733.

${ }^{66}$ Braudel, 733. He states: 'Cycles, intercycles, crises structurelles cachent ici les régularités, les permanence de systems, certains ont dit de civilisations économiques - c'est-à-dire de de vieilles attitudes de penser et d'agir, de cadres résistants, durs à mourir, parfois contre toute logique.'

67 Ibid, 111. My emphasis.
} 


\section{'The art of the novel'}

Although different times and places produce unique social configurations, these often reflect universal themes of human representation. For instance, although the question of how to achieve social change while maintaining respect for individual rights has arrested European thought largely since the humanism of the Renaissance, in the context of the rise of ideological dictatorships in twentieth-century Europe this tension became acute. What can narratives about life under these regimes tell us about contemporary issues facing Europe today? In Arthur Koestler's Darkness at Noon (1940), for example, the subjective reawakening of a Bolshevik revolutionary during the time of Stalin's show trials exemplifies how the attempt to manifest social progress through Marxist-Leninist instrumentality had become a 'movement without scruples' that eradicated 'whosoever could not follow her crooked course.'68 Similarly, in Andrei Makine's Siberian Bildungsroman, Once Upon the River Love (1998), we are shown the devastating personal implications of the sacrifice of personal values to Soviet materialism, and the failure of the Soviet system, despite this sacrifice, to improve the lives of Russian citizens. In The Lives of Others (2006), Florian Henckel von Donnersmarck's film about the Stasi in the GDR, we come to understand the emptiness of individual life when interpersonal trust is destroyed by the totalitarian state apparatus.

In Danilo Kiš' Encyclopedia of the Dead (A Whole Life) (1983), likewise, the value of the individual is exalted by means of a grieving daughter's discovery of a mysterious book containing the detailed story of her father's unexceptional life. Written at a time when the socialist organisation of life in Kiš' native Yugoslavia began to give way to an even more homogenous understanding of 'the collective' under ethno-nationalism, Kiš' story about an ordinary man stands as testament to 'all the forgotten and anonymous dead' of twentieth century Europe. ${ }^{69}$ For Kiš, the ideology of nationalism, like the ideology of communism, was ontologically opposed to the notion of human history, meaning that 'as soon as an individual life is organized on the basis of ethno-national historical hierarchies, that life is swallowed up.'70 As in the narratives above, therefore, Kiš’ short story underscores the primacy of the individual and the dangers inherent in any means of social organization that demands the sacrifice of personal values to the collective. What these literary texts encapsulate, therefore, is not the failure of communism as a social and economic system, but the fundamental incompatibility of any totalizing social system with the subjective values of human life.

Literature, which Kundera maintains is 'grounded in the relativity and ambiguity of all things human, ${ }^{71}$ can thus speak out to us from unfamiliar time periods to remind us of the conditions in which human life prospers and develops, and those conditions in which it deteriorates. The above narratives remain pertinent in Europe today, as waves of toxic populism and nationalism sweep the continent and new authoritarian regimes flourish in places where the communist legacy is still within living memory. We can seek in historical literature enlightenment on contemporary European issues of social and cultural complexity, in recognition of the fact that these are often modern

\footnotetext{
68 Arthur Koestler, Darkness at Noon, (New York: Macmillan, 1941): 76.

${ }^{69}$ For historian Angus Calder, the story 'speaks for all the forgotten and anonymous dead' in twentieth-century Europe. Cited in Mark Thompson, 'Introduction: Danilo Kiš and pocket-sized novels', in Danilo Kiš, Encyclopedia of the Dead, (London: Penguin, 2015): xvii.

${ }^{70}$ Aleksander Hemon, cited in Thompson, xvii.

${ }^{71}$ Ibid, 14.
} 
iterations of human dilemmas that Europeans have grappled with for generations. By encouraging our students to read and watch these texts, we provide them with means to understand not only the catastrophic human cost of ideological regimes, but also the kinds of circumstances that lead individuals to support to them in the first place, even when they are so diametrically opposed to their own wellbeing. As Kundera maintains, the great 'art of the novel', is its ability to hold 'the world of life under a permanent light' and protect it from the 'forgetting of being.' ${ }^{2}$ In other words, this is why we need stories to make sense of our world, and to remind us of who and what we are in different environments - mere cognizance of historical or cultural facts is not enough.

\section{Conclusion: Learning through the Narrative Epistemology}

As this essay has suggested, the benefits of literature and film as teaching tools lay precisely in their fictional capabilities. This is because the literary epistemology enlightens us to different cultures and times by expanding our sympathies to human experiences in ways that real life or historical fact cannot. While there are certainly caveats to using literary texts in an academic environment of historical or social inquiry, as long we approach them from within the knowledge that they do not aim to establish fact, but to instead provoke an emotional response from us, such texts remain useful pedagogical tools for fostering cultural and historical literacy amongst our European Studies students.

Just as a historian aims to analyze the determinants of a historical situation, we as readers and audience members seek to understand to the messages and paradoxes a literary narrative is trying to tell us. This enables us to penetrate the dynamics of a particular environment not simply from a position of detached social analysis, but from one of critical cultural contextualization by means of experiencing that environment through the eyes and emotions of other human beings. In the age of a 'globalised' Europe, narrative can thus serve as a space to address common themes between different peoples, but also to illuminate the ways in which different peoples respond dissimilarly to common problems.

The question of how to make information so geographically, historically and culturally distant from our Australian students meaningful and manageable in a teaching environment can thus be answered, in part at least, by film and literature. The literary imagination is a unique tool we can use to build the cultural breadth and historical depth to broach contemporary European affairs when the necessary signposts are lacking. This is because narrative provides the context to help students understand complex dynamics at play in unfamiliar situations, and makes this context meaningful by putting it into humanistic, not scientific terms. It is above all an epistemology based on the use of 'empathy' as a device to deepen historical and cultural understanding.

Such texts, of course, do not take the place of rigorous theoretical, political or historical inquiry and debate. Neither should novels or films be read uncritically as historical documents. It is perhaps more accurate to say that they engage in the broader task of 'documenting' and therefore witnessing and memorialising what life was, and is, for others in different situations to us. We should see these texts in teaching terms as a way in - they are the building blocks with which we can begin to construct an

${ }^{72}$ Ibid, 5 . 
Jenkins, ANZJES 9(2)

understanding of the complex culturally and historically determined characteristics that drive European affairs today. 